\title{
Гібридна артеріальна реконструкція в лікуванні хворих з ішемічною формою синдрому діабетичної стопи та багаторівневим стенотично-оклюзійним ураженням артерій нижньої кінцівки
}

\author{
С. М. Діденко \\ Клінічна лікарня «Феофанія» Державного управління справами, м. Київ
}

\section{The hybrid arterial reconstruction in treatment of patients, suffering the ischemic form of the diabetic foot syndrome and multi-level stenotic-occlusive affection of the lower extremity arteries}

\author{
S. M. Didenko \\ Clinical Hospital «Feofania», Kyiv
}

\section{Реферат}

Мета. Аналіз результатів хірургічного лікування хворих з ішемічною формою синдрому діабетичної стопи (IФ СДС) та багаторівневим стенотично-оклюзійним ураженням (СОУ) артерій нижньої кінцівки (НК).

Матеріали і методи. Проаналізовані результати хірургічного лікування 164 хворих 3 цукровим діабетом (Цд) 2-го типу, ускладненим ІФ ССД, та хронічною критичною ішемією НК на тлі поєднаного СОУ артерій стегнового та підколінногомілкового сегментів (ПГС). За характером виконаного оперативного втручання пацієнтів розподілили на три групи. До групи 1 включили 61 пацієнта, якому була виконана відкрита реконструкція артерій стегнового сегмента без втручання на артеріях ПГС; до групи 2 - 38 пацієнтів, яким була виконана відкрита дворівнева реконструкція артерій; до групи 3 - 65 пацієнтів, яким була виконана гібридна артеріальна реконструкція.

Результати. У паціентів групи 1 показник первинної прохідності зони стегнової реконструкції становив 65,6\%, вторинної - 81,9\%, частка високих ампутацій - 18\%, смертність - 11,5\%; у пацієнтів групи 2 - 89,5, 92,1, 5,2 та 7,9\% відповідно; у пацієнтів групи 3 - 81,5, 93,9, 7,7 та 4,6\% відповідно.

Висновки. У пацієнтів з поєднаним СОУ артерій ПГС та поверхневої стегнової артерії (ПСА) ізольоване відновлення прохідності ПСА без втручання на артеріях ПГС не є достатнім, про що свідчать достовірно вищі смертність - 11,5\% та частка високих ампутацій - 14,8\% (р < 0,001). Показники первинної і вторинної прохідності зони артеріальної реконструкції та частки високих ампутацій після відкритих дворівневих та гібридних реконструктивних операцій порівнянні - 89,5 та 81,5\%, 94,7 та 96,9\%, 2,6 та 3,1\% відповідно (р > 0,05). А смертність після відкритих дворівневих операцій достовірно вища, ніж після гібридних реконструктивних - 7,9 та 4,6\% відповідно (p < 0,05). Тому при поєднаному СОУ ПСА та артерій ПГС виконання саме гібридної артеріальної реконструкції слід вважати оптимальною хірургічною тактикою.

Ключові слова: цукровий діабет; хронічна критична ішемія нижньої кінцівки; гібридна артеріальна реконструкція; ішемічна форма синдрому діабетичної стопи.

Abstract

Objective. Analysis of results of surgical treatment in patients, suffering ischemic form of the diabetic foot syndrome (IF DFS) and multilevel stenotic-occlusive affection (SOA) of the lower extremity arteries.

Materials and methods. There were analyzed the results of surgical treatment in 164 patients, suffering diabetes mellitus (DM) of the Type II, complicated by IF DFS, and chronic critical ischemia of the lower extremity on background of the combined SOA of arteries of femoral and popliteo-tibial segments (PTS). The patients were divided into three Groups in accordance to the operation performed. Into Group I 61 patients were included, to whom open arterial reconstruction in femoral segment without intervention on the PTS arteries was performed; to Group II - 38 patients, in whom open two-level arterial reconstruction was done; to Group III - 65 patients, in whom a hybrid arterial reconstruction was performed.

Results. In the Group I patients the index of primary passability of the femoral reconstrucrion zone have constituted $65.6 \%$, secondary $-81.9 \%$, the high amputation part $-18 \%$, mortality $-11.5 \%$; in the patient of Group II $-89.5,92.1,5.2$ and $7.9 \%$ accordingly; in the patients of Group III - 81.5, 93.9, 7.7 and $4.6 \%$ accordingly.

Conclusion. In the patients, suffering combined SOA in the PTS arteries and superficial femoral artery (SFA) the isolated restoration of SFA passability without intervention on the PTS arteries have appeared not sufficient, witnessed by trustworthily highest mortality $-11.5 \%$ and percentage of high amputations performed- $14.8 \%(p<0.001)$. The indices of primary and secondary passability of the arterial reconstruction zone and percentage of high amputations performed after open two-level and the hybrid reconstructive operations are quite similar -89.5 and $81.5 \%, 94.7$ and $96.9 \%, 2,6$ and $3.1 \%$ accordingly (p $>0.05$ ). While mortality after open two-level operations is trustworthily higher, than after the hybrid reconstructive -7.9 and $4.6 \%$ accordingly $(\mathrm{p}<0.05)$. That is why in the combined SOA of SFA and arteries of PTS the performance of the hybrid arterial reconstruction must be regarded first of all as optimal surgical tactic.

Keywords: diabetes mellitus; chronic critical ischemia of the lower extremity; the hybrid arterial reconstruction; ischemic form of the diabetic foot syndrome. 
За даними Міжнародної діабетичної федерації, хворих 3 цукровим діабетом (ЦД) серед дорослого населення в 2015 р. було близько 250 млн. Спостерігається чітка тенденція до неухильного зростання абсолютної кількості хворих з ЦД у майбутньому.

Стенотично-оклюзійне ураження (СОУ) периферичних артерій у хворих з Цд розвивається на $10-15$ років раніше, ніж у хворих з облітеруючим атеросклерозом без діабету, його перебіг швидший, більш злоякісний та частіше призводить до тяжкого виразково-некротичного ураження стопи. Особливістю діабетичного ураження артеріального русла є багаторівневий стенотично-оклюзійний процес в артеріях середнього і малого калібру [1].

Особливо складних тактичних та технічних рішень потребує група хворих з ішемічною формою (IФ) синдрому діабетичної стопи (СДС) у поєднанні з оклюзією поверхневої стегнової артерії (ПСА) та СОУ артерій підколінно-гомілкового сегмента (ПГС), застосування у яких стандартних методів артеріальної реконструкції не завжди ефективне [2].

Із середини 90-х років XX сторіччя бурхливо розвиваються методи ендоваскулярної хірургії СОУ артерій нижньої кінцівки (НК) як допоміжної, так і самостійної процедури [3].

Стандартом лікування хронічної критичної ішемії НК (ХКІНК) є відкрита хірургічна артеріальна реконструкція. Проте цей метод успішно застосовують у пацієнтів із спроможним дистальним артеріальним руслом без тяжкої супутньої патології. Ураження артерій ПГС при ЦД спостерігають у 20 разів частіше, ніж при атеросклерозі. У зв'язку з цим виникає необхідність виконання дистальної та ультрадистальної артеріальних реконструкцій [4]. Одним із способів вирішення проблеми лікування хворих із багаторівневим СОУ артерій НК є виконання гібридного оперативного втручання - відкритої артеріальної реконструкції в поєднанні з ендоваскулярним втручанням [5].

Мета дослідження: аналіз результатів хірургічного лікування хворих з ІФ СДС та багаторівневим СОУ артерій НК.

\section{Матеріали і методи дослідження}

Проаналізовані результати хірургічного лікування 164 хворих з ЩД 2-го типу, ускладненим ІФ СДС, та ХКІНК на тлі поєднаного СОУ артерій стегнового та підколінно-гомілкового сегментів. Усі пацієнти отримували лікування в Центрі судинної хірургії Клінічної лікарні «Феофанія» Державного управління справами протягом 2010 - 2017 pp. Чоловіків було 86 (52,4\%), жінок - 78 (47,6\%) у віці від 56 до 82 років. Середній вік пацієнтів становив (64,2 \pm 5,3) року.

Усім пацієнтам вимірювали сегментарний тиск на гомілкових артеріях та визначали індекс регіонарного систолічного тиску (IPCT); проводили ультразвукове дуплексне сканування артерій НК з вивченням характеру кровотоку на апараті «Flexfocus» виробництва «BK medical». Ангіографію виконували шляхом пункції загальної стегнової артерії (ЗСА) під контролем ультразвуку (Пат.
України на корисну модель №114970) за допомогою ангіографічної системи «Euroampli ALIEN» виробництва «EUROCOLUMBUS SRL».

За характером виконаного оперативного втручання пацієнтів розподілили на три групи. До групи 1 включили 61 (37,2\%) пацієнта, якому, незважаючи на наявність СОУ артерій ПГС, було відновлено прохідність ПСА без втручання на артеріях ПГС шляхом шунтування та ендартеректомії - у 57 (93,4\%) та 4 (6,6\%) пацієнтів відповідно. Із 57 хворих, яким було виконано шунтування, у 22 (38,6\%) дистальний анастомоз сформовано з підколінною артерією (ПкА) вище щілини колінного суглоба, у 35 (61,4\%) - нижче щілини колінного суглоба; якщо проксимальний анастомоз формували із ЗСА, застосовували розроблену методику доступу до неї (Пат. України № 114969). У всіх 22 хворих, яким було виконано шунтування вище щілини колінного суглоба, застосовано суцільний синтетичний протез. Із 35 хворих, яким було виконано шунтування нижче щілини колінного суглоба, у 31 (88,6\%) застосували комбінований шунт (проксимальна частина шунта - синтетичний протез, дистальна - сегмент великої підшкірної вени), у 4 (11,4\%) - суцільний синтетичний протез.

До групи 2 включили 38 (23,2\%) пацієнтів, яким було виконано відкриту дворівневу артеріальну реконструкцію. На рівні ПСА у 3 (7,9\%) пацієнтів виконали ендартеректомію $з$ пластикою артерії латкою, у 35 (92,1\%) - шунтування, 3 них у 10 (28,6\%) комбінованим шунтом, у 25 (71,4\%) суцільним синтетичним протезом, у 28 (80,0\%) вище щілини колінного суглоба, у 7 (20,0\%) нижче щілини колінного суглоба. На рівні ПГС усім 38 хворим виконали шунтування реверсованою великою підшкірною веною. У разі формування дистального анастомоза з тильною артерією стопи застосовували розроблену методику доступу до неї (Пат. України № 115008). Після формування дистального анастомоза з тильною артерією стопи або з передньою великогомілковою артерією у 12 (54,6\%) із 22 хворих $з$ метою уникнення пошкодження передніх великогомілкових вен під час ортотопічного проведення шунта, яке може спричинити складно контрольовану рясну кровотечу, шунт з переднього фасціального простору гомілки до підколінної ямки проводили через штучний отвір у верхній третині великогомілкової кістки, просвердлений за допомогою дриля (Пат. України №64146).

До групи 3 включили 65 (39,6\%) пацієнтів, яким було виконано гібридну артеріальну реконструкцію. Під гібридною артеріальною реконструкцією ми розуміємо поєднання відкритої операції з метою відновлення прохідності ПСА та ендоваскулярного втручання на артеріях ПГС протягом одного хірургічного втручання на одному операційному столі. Прохідність ПСА відновлювали шляхом ендартеректоміі - у 6 (9,2\%) хворих або шунтування - у 59 (90,8\%) хворих, із них у 11 (18,6\%) комбінованим шунтом, у 48 (81,4\%) суцільним синтетичним протезом, у 49 (83,1\%) вище щілини колінного суглоба, у 10 (16,9\%) нижче щілини колінного суглоба. Ендоваскулярне втручання виконували шляхом балонної ангіопластики (БАП) 


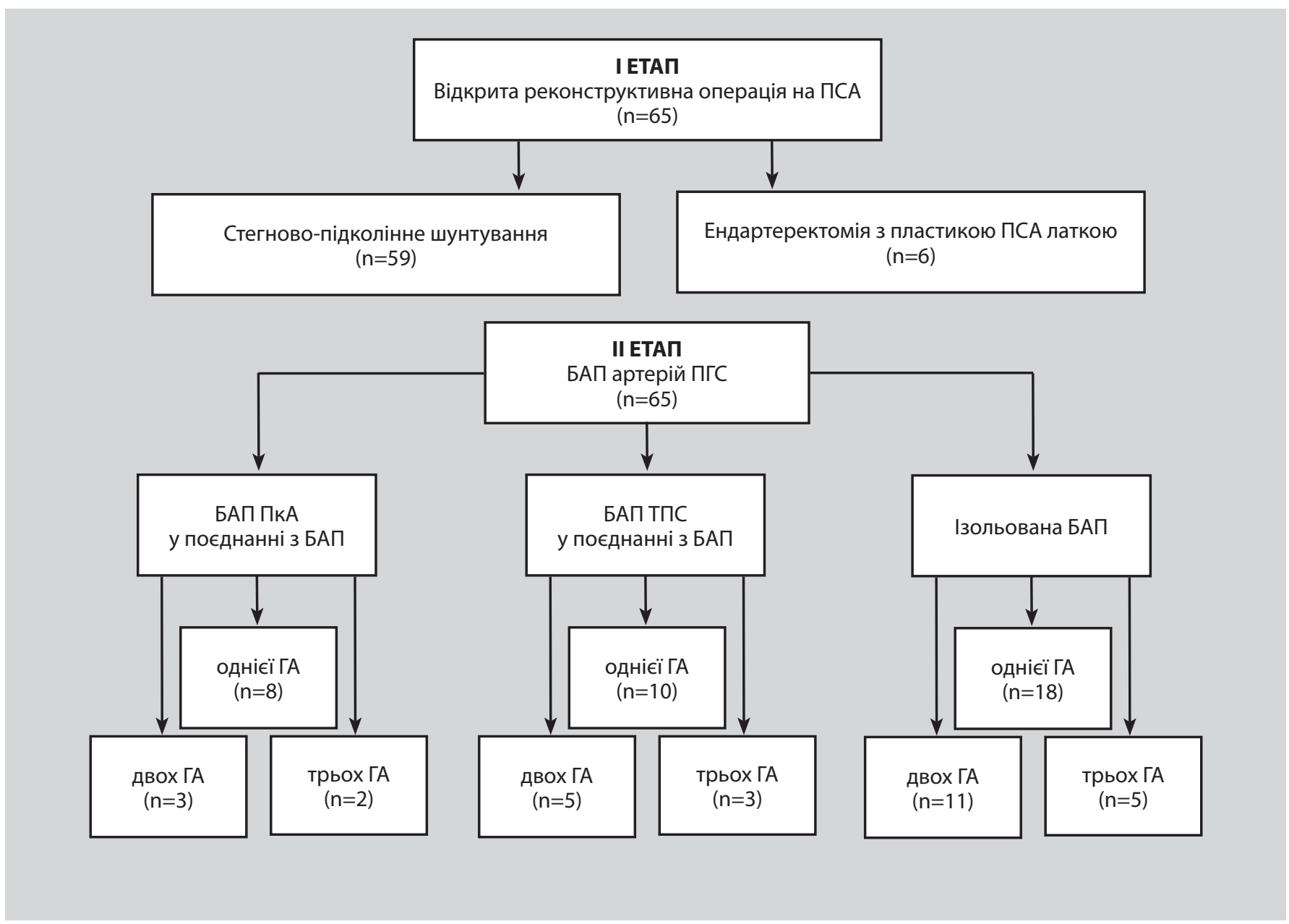

Послідовность виконання етапів гібридної артеріальної реконструкцї та варіанти ендоваскулярних втручань на артеріях ПГС у пацієнтів групи 3.

ПкА, тібіоперонеального стовбура (ТПС), гомілкових артерій (ГА) у різних комбінаціях (див. рисунок).

Результати реконструктивних операцій оцінювали, порівнюючи зміни клінічного статусу пацієнта протягом періоду післяопераційного спостереження, який становив у середньому 12 міс, з його клінічним статусом перед операцією згідно зі шкалою R. B. Rutherford і співавторів (1997). Також вивчали та порівнювали перед- та післяопераційні показники IPCT, транскутанного напруження кисню $\left(\mathrm{TcpO}_{2}\right)$, первинної та вторинної прохідності зони артеріальної реконструкції (ЗАР), частки високих ампутацій та смертності.

\section{Результати}

У групі 1 протягом періоду післяопераційного спостереження у 21 (34,4\%) пацієнта виник тромбоз ЗАР у ділянці ПСА. Усім цим пацієнтам виконали тромбектомію із ЗАР та інтраопераційну ангіографію. У 7 хворих застосували реконструкцію анастомозів, у 4 - решунтування. БАП артерій ПГС виконали 10 хворим: у 8 отримали позитивний результат, 2 виконали високу ампутацію. Із 11 хворих, яким ендоваскулярне втручання на артеріях ПГС не виконува- ли, у 4 результат був позитивний, 7 виконали високу ампутацію. Померли 7 пацієнтів. Показник первинної прохідності ЗАР становив 65,6\%, вторинної - 85,2\%, частка високих ампутацій - 14,8\%, смертність - 11,5\%.

Середній доопераційний показник ІРСТ становив 0,24 $\pm 0,07$ (p < 0,01). У 28 (45,9\%) оперованих пацієнтів визначили значне поліпшення (+3) клінічного стану за шкалою R. B. Rutherford і співавторів (1997). Середній післяопераційний показник ІРСТ становив 0,84 $\pm 0,05$ ( $><0,001)$. У 19 (31,1\%) хворих визначили помірне поліпшення клінічного стану (+2). Середній післяопераційний показник IPCT становив 0,66 $\pm 0,05$ ( $<<0,001)$. Таким чином, у 47 (77,0\%) хворих групи 1 відмічено значне і помірне поліпшення. Середній приріст показника IРСТ у хворих зі значним та помірним поліпшенням становив 0,46 $\pm 0,04$ ( $<<0,001)$.

Рівень ТсрО 2 визначали у 19 (31,1\%) хворих із значним поліпшенням (+3) за шкалою R. B. Rutherford і співавторів. Середнє значення ТсрО 2 до операції становило: у положенні пацієнта сидячи $(10,4 \pm 2,3)$ мм рт. ст. (p < 0,001); у положенні лежачи $(5,7 \pm 3,2)$ мм рт. ст. (p > 0,05). Після операції середнє значення ТсрО 2 збільшилося: у положенні сидячи до $(40,4 \pm 5,9)$ мм рт. ст. (p < 0,001); у положен- 


\begin{tabular}{|c|c|c|c|c|c|c|c|c|c|}
\hline \multirow{2}{*}{ Критерій } & \multicolumn{9}{|c|}{ Статистичні показники } \\
\hline & M1 & $\mathrm{m} 1$ & $\mathrm{n}$ & M2 & $\mathrm{m} 2$ & $\mathrm{~N}$ & $\mathrm{t}$ & $f$ & $p$ \\
\hline \multicolumn{10}{|c|}{ Середній приріст IPCT } \\
\hline групи 1-2 & 0,46 & 0,04 & 61 & 0,65 & 0,08 & 38 & 2,12 & 97 & $<0,05$ \\
\hline групи 2-3 & 0,65 & 0,08 & 38 & 0,59 & 0,07 & 65 & 0,56 & 101 & $>0,05$ \\
\hline групи 1 - 3 & 0,46 & 0,04 & 61 & 0,59 & 0,07 & 65 & 1,61 & 124 & $<0.05$ \\
\hline \multicolumn{10}{|c|}{ Середній приріст ТсрО ${ }_{2}$} \\
\hline групи 1-2 & 26,3 & 5,7 & 61 & 41,6 & 5,2 & 38 & 1,98 & 97 & $<0,05$ \\
\hline групи 2 - 3 & 41,6 & 5,2 & 38 & 38,7 & 5,5 & 65 & 0,38 & 101 & $>0,05$ \\
\hline групи 1 - 3 & 26,3 & 5,7 & 61 & 38,7 & 5,5 & 65 & 1,57 & 124 & $<0,05$ \\
\hline $\begin{array}{ll}\text { Примітка. } & \mathrm{M} \\
& \mathrm{m} \\
& \text { по } \\
& \text { гр }\end{array}$ & $\begin{array}{l}\text { груп } \\
\text { ерій С }\end{array}$ & $\begin{array}{l}\text { е перь } \\
\text { похиє } \\
\text { озмір } \\
\text {-та; f }\end{array}$ & и пє & $\begin{array}{l}\text { групи } \\
\text { юван } \\
\text { орівн } \\
\text { в своє }\end{array}$ & $\begin{array}{l}\text { - cepe } \\
\text { in; m2 } \\
\text { ï груп } \\
p-3 н\end{array}$ & рози & $\begin{array}{l}\text { е друг } \\
\text { артна } \\
\text { рки д }\end{array}$ & $\begin{array}{l}\text { івнюв } \\
\text { 5ка дк } \\
\text { орівн }\end{array}$ & $\begin{array}{l}\text { групи, } \\
\text { ої }\end{array}$ \\
\hline
\end{tabular}

Таблиця 2. Порівняння результатів хірургічного лікування пацієнтів груп 1, 2 та 3

\begin{tabular}{|c|c|c|c|c|c|c|c|c|c|c|c|c|}
\hline \multirow{2}{*}{\multicolumn{2}{|c|}{ Критерій }} & \multicolumn{11}{|c|}{ Статистичні показники } \\
\hline & & N1 & $\mathrm{n} 1$ & P1,\% & $\mathrm{m} 1$ & N2 & $\mathrm{n} 2$ & $\mathrm{P} 2, \%$ & $\mathrm{~m} 2$ & $\mathrm{t}$ & $f$ & $p$ \\
\hline \multicolumn{13}{|c|}{ Покращення $(+3,+2)$ за R. B. Rutherford } \\
\hline \multicolumn{2}{|c|}{ групи1-2 } & 47 & 61 & 77,1 & 0,10 & 35 & 38 & 92,1 & 0,15 & 0,84 & 97 & $<0,05$ \\
\hline \multicolumn{2}{|l|}{ групи 2-3 } & 35 & 38 & 92,1 & 0,15 & 60 & 65 & 89,2 & 0,11 & 0,15 & 101 & $>0,05$ \\
\hline \multicolumn{2}{|l|}{ групи 1-3 } & 47 & 61 & 77,0 & 0,10 & 60 & 65 & 92,3 & 0,11 & 0,82 & 124 & $<0,05$ \\
\hline \multicolumn{13}{|c|}{ Первинна прохідність ЗАР } \\
\hline \multicolumn{2}{|c|}{ групи 1-2 } & 40 & 61 & 65,6 & 0,08 & 34 & 38 & 89,5 & 0,15 & 1,43 & 97 & $<0,05$ \\
\hline \multicolumn{2}{|l|}{ групи 2-3 } & 34 & 38 & 89,5 & 0,15 & 53 & 65 & 81,5 & 0,10 & 0,45 & 101 & $>0,05$ \\
\hline \multicolumn{2}{|l|}{ групи 1-3 } & 40 & 61 & 65,6 & 0,08 & 53 & 65 & 81,5 & 0,10 & 1,21 & 124 & $<0,05$ \\
\hline \multicolumn{13}{|c|}{ Вторинна прохідність ЗАР } \\
\hline \multicolumn{2}{|c|}{ групи 1-2 } & 52 & 61 & 85,2 & 0,11 & 36 & 38 & 94,7 & 0,15 & 0,50 & 97 & $<0,05$ \\
\hline \multicolumn{2}{|l|}{ групи 2-3 } & 36 & 38 & 94,7 & 0,15 & 63 & 65 & 96,9 & 0,12 & 0,11 & 101 & $>0,05$ \\
\hline \multicolumn{2}{|l|}{ групи 1-3 } & 52 & 61 & 85,2 & 0,11 & 63 & 65 & 96,9 & 0,12 & 0,72 & 124 & $<0,05$ \\
\hline \multicolumn{13}{|c|}{ Частка високих ампутацій } \\
\hline \multicolumn{2}{|c|}{ групи 1-2 } & 9 & 61 & 14,8 & 0,02 & 1 & 38 & 2,6 & 0,00 & 6,26 & 97 & $<0,001$ \\
\hline \multicolumn{2}{|l|}{ групи 2-3 } & 1 & 38 & 2,6 & 0,00 & 2 & 65 & 3,1 & 0,00 & 0,78 & 101 & $>0,05$ \\
\hline \multicolumn{2}{|l|}{ групи 1-3 } & 9 & 61 & 14,8 & 0,02 & 2 & 65 & 3,1 & 0,00 & 6,06 & 124 & $<0,001$ \\
\hline \multicolumn{13}{|l|}{ Летальність } \\
\hline \multicolumn{2}{|l|}{ групи 1-2 } & 7 & 61 & 11,5 & 0,01 & 3 & 38 & 7,9 & 0,01 & 1,84 & 97 & $<0,05$ \\
\hline \multicolumn{2}{|l|}{ групи 2-3 } & 3 & 38 & 7,9 & 0,01 & 3 & 65 & 4,6 & 0,01 & 2,34 & 101 & $<0,05$ \\
\hline \multicolumn{2}{|l|}{ групи 1-3 } & 7 & 61 & 11,5 & 0,01 & 3 & 65 & 4,6 & 0,01 & 4,35 & 124 & $<0,001$ \\
\hline \multicolumn{13}{|c|}{$\begin{array}{ll}\text { Примітка. } & \text { N1 - кількість спостережень критерію в першій порівнюваній групі; N2 - кількість спостережень критерію в другій } \\
\text { порівнюваній групі; } \mathrm{n} 1 \text { - загальна кількість спостережень в першій порівнюваній групі; n2 - загальна кількість } \\
\text { спостережень в другій порівнюваній групі; P1 - відносна величина, що описує кількість спостережень критерію в } \\
\text { першій порівнюваній групі; Р2 - відносна величина, що описує кількість спостережень критерію в другій } \\
\text { порівнюваній групі; m1 - середня (стандартна) похибка першої порівнюваної групи; m2 - середня (стандартна) } \\
\text { похибка другої порівнюваної групи; t - критерій Ст'юдента; - кількість ступенів свободи; р-значущість. }\end{array}$} \\
\hline
\end{tabular}

ні лежачи до $(28,1 \pm 4,8)$ мм рт. ст. (p < 0,001). Приріст по-

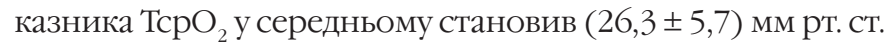
$(\mathrm{p}<0,001)$. Різниця між значеннями ТсрО 2 до і після операції у положенні сидячи та у положенні лежачи статистично значуща $(\mathrm{p}<0,001)$.

У групі 2 протягом періоду післяопераційного спостереження у 4 (10,5\%) хворих виник тромбоз ЗАР. Усім цим хворим виконали тромбектомію із ЗАР та інтраопераційну ангіографію, у 3 - із реконструкцією анастомозів. Прохідність дворівневої артеріальної реконструкції вдалося відновити у 2 пацієнтів. Високу ампутацію викона- ли у 1 пацієнта. Померли 3 хворих. Показник первинної прохідності ЗАР становив 89,5\%, вторинної - 94,7\%, частка високих ампутацій - 2,6\%, смертність -7,9\%.

Середній доопераційний показник ІРСТ становив 0,19 $\pm 0,06(p<0,01)$. У $31(81,6 \%)$ оперованого пацієнта визначили значне поліпшення (+3) клінічного стану. Середній післяопераційний показник ІРСТ становив 0,93 \pm 0,04 (p < 0,001). У 4 (10,5\%) хворих визначили помірне поліпшення (+2). Середній післяопераційний ІРСТ становив 0,79 0,05 (р < 0,001). Таким чином, у 35 (92,1\%) хворих групи 2 відмічено значне і помірне поліпшення. Середній при- 
ріст IРСТ у хворих зі значним та помірним поліпшенням становив 0,65 $\pm 0,08(\mathrm{p}<0,001)$.

Рівень ТсрО 2 визначали у 15 (39,5\%) хворих із значним поліпшенням (+3). Середнє значення ТсрО 2 до операції становило: у положенні сидячи $(8,7 \pm 2,6)$ мм рт. ст. ( $<<0,01)$; у положенні лежачи $(6,2 \pm 2,9)$ мм рт. ст. (p > 0,05). Після операції середне значення ТсрО збільшилося: у положенні сидячи до $(51,8 \pm 5,2)$ мм рт. ст. (p < 0,001); у положенні лежачи до $(46,2 \pm 4,3)$ мм рт. ст. $(\mathrm{p}<0,001)$. Приріст показника ТсрО 2 у середньому становив (41,6 $5,2)$ мм рт. ст. $(\mathrm{p}<0,001)$. Різниця між значеннями ТсрО до і після операції у положенні сидячи та у положенні лежачи статистично значуща $(\mathrm{p}<0,001)$.

У групі 3 протягом періоду післяопераційного спостереження у 12 (18,5\%) пацієнтів виник тромбоз ЗАР. Усім цим пацієнтам виконали тромбектомію та інтраопераційну ангіографію, за допомогою якої було знайдено рестеноз в анастомозах стегново-підколінного шунта та на рівні ПГС, з приводу чого у 4 хворих застосували реконструкцію анастомозів, у 3 - решунтування та виконали повторну БАП артерій ПГС усім 12 хворим. У 10 хворих отримали хороший результат, у 2 досягти регресу ішемії не вдалося, їм виконали ампутацію на рівні гомілки. Померли 3 хворих. Показник первинної прохідності 3АР становив 81,5\%, вторинної - 96,9\%, частка високих ампутацій - 3,1\%, смертність - 4,6\%.

Середній доопераційний показник ІРСТ становив 0,21 $\pm 0,05$ ( $<$ 0,001). У 53 (81,5\%) оперованих пацієнтів визначили значне поліпшення (+3). Середній післяопераційний показник IPCТ становив 0,88 \pm 0,04 (p < 0,001). У 7 (10,8\%) хворих визначили помірне поліпшення (+2). Середній післяопераційний показник IPCТ становив 0,72 $\pm 0,05$ ( $<<0,001)$. Таким чином, у 60 (92,3\%) хворих відмічено значне і помірне поліпшення. Середній приріст IPCT у хворих зі значним та помірним поліпшенням становив 0,59 $\pm 0,07$ ( $<<0,001)$.

Рівень ТсрО 2 визначали у $23(35,4 \%)$ хворих із значним поліпшенням (+3). Середнє значення ТсрО 2 до операції становило: у положенні сидячи $(9,4 \pm 2,6)$ мм рт. ст. ( $<<0,01)$; у положенні лежачи $(5,3 \pm 2,9)$ мм рт. ст. (p > 0,05). Після операції середнє значення ТсрО з збільшилося: у положенні сидячи до $(49,7 \pm 4,5)$ мм рт. ст. (р < 0,001); у положенні лежачи до $(41,7 \pm 4,9)$ мм рт. ст. $(\mathrm{p}<0,001)$. Приріст показника ТсрО 2 у середньому становив $(38,7 \pm$ $5,5)$ мм рт. ст. ( $<0,001)$. Різниця між значеннями ТсрО до і після операції у положенні сидячи та у положенні лежачи статистично значуща $(\mathrm{p}<0,001)$.

Ми порівняли показники регіонарного кровообігу і результати хірургічного лікування у трьох досліджуваних групах пацієнтів із використанням статистичних показників (табл. 1, 2).

\section{Обговорення}

У хворих групи 1 відновлення прохідності ПСА без втручання на артеріях ПГС мало незадовільні результати: найвищий показник смертності - 11,5\%, який достовірно від- різнявся від показників смертності у групі $2(\mathrm{p}<0,05)$ та групі 3 (р < 0,001), частка високих ампутацій становила 14,8\% та достовірно відрізнялася від частки високих ампутацій у групі 2 та групі 3 ( $<<0,001)$, достовірно найгірший показник за шкалою R. B. Rutherford і співавторів (1997) - 77,1\% (p < 0,05). Відмова від реконструкції артерій ПГС суттєво погіршує кровопостачання стопи та перспективи загоювання виразково-некротичних уражень і $є$ провокуючим фактором тромбозу ЗАР стегнового сегмента.

Найкращі результати післяопераційного збільшення показників IPCT та ТсрО 2 спостерігали у групах 2 та 3 $0,65 \pm 0,08$ i $0,59 \pm 0,07(\mathrm{p}>0,05)$ та $(41,6 \pm 5,2)$ i $(38,7 \pm 5,5)$ мм рт. ст. (p > 0,05) відповідно.

Показники первинної та вторинної прохідності ЗАР і частки високих ампутацій у хворих груп 2 та 3 порівнянні - 89,5 і 81,5\%, 94,7 і 96,9\% та 2,6 і 3,1\% відповідно (р > 0,05). Проте смертність у групі 2 достовірно вища в порівнянні із смертністю у групі 3 - 7,9 та 4,6\% відповідно (р < 0,05). Зважаючи на технічну складність виконання, травматичність та довготривалість дворівневих відкритих реконструкцій та майже вдвічі вищу смертність, виконувати ці операції у пацієнтів похилого та старечого віку з тяжкою супутньою патологією недоцільно.

Таким чином, методом вибору хірургічного лікування хворих з ЦД та ХКІНК при поєднанні СОУ артерій ПГС та ПСА є гібридна артеріальна реконструкція, оскільки після неї майже вдвічі нижча смертність, а інші показники порівнянні з відповідними показниками при дворівневих відкритих реконструкціях.

\section{Висновки}

1. У пацієнтів з поєднаним СОУ артерій ПГС та ПСА ізольоване відновлення прохідності ПСА без втручання на ПГС не є достатнім, про що свідчать достовірно вищі показники смертності - 11,5\% та частки високих ампутацій $-14,8 \%(\mathrm{p}<0,001)$.

2. Після відкритих дворівневих та гібридних реконструктивних операцій показники первинної (89,5 і 81,5\%) та вторинної (94,7 і 96,9\%) прохідності ЗАР та частки високих ампутацій (2,6 і 3,1\%) порівнянні (р > 0,05), однак смертність після відкритих дворівневих операцій достовірно вища, ніж після гібридних реконструктивних - 7,9 та 4,6\% відповідно ( $<$ 0,05). Тому при поєднанні СОУ ПСА та артерій ПГС саме виконання гібридної артеріальної реконструкції слід вважати оптимальною хірургічною тактикою.

\section{Підтвердження}

Фінансування. За власні кошти автора.

Конфлікт інтересів. Автор заявяє про відсутність конфлікту інтересів щодо цього рукопису.

\section{References}

1. Das SK, Yuan YF, Li MQ. Predictors of delayed wound healing after successful isolated below-the-knee endovascular intervention in patients with ischemic foot ulcers. J Vasc Surg. 2018;67(4):1181-90. doi: 10.1016/j.jvs.2017.08.077. 
2. Shah B, Rockman CB, Guo Y. Diabetes and vascular disease in different arterial territories. Diabet Care. 2014;37(6):1636-42. doi: 10.2337/ dc13-2432.

3. Boyko VV, Ivanova YV, Kryvoruchko IA, Didenko SN, Mushenko EV, KorobovAM, et al. Treatment of ischemic form of the diabetic foot syndrome.. Klin khir. 2018;85(2):18-21. doi: 10.26779/25221396.2018.02.18.

4. Thiruvoipati T, Kielhorn CE, Armstrong EJ. Peripheral artery disease inpatients with diabetes: Epidemiology, mechanisms, andoutcomes. World J Diabetes. 2015; 6(7):961-9. doi: 10.4239/wjd.v6.i7.961.
5. Takayama T, Matsumura JS. Complete Lower Extremity Revascularization via a Hybrid Procedure for Patients with Critical Limb Ischemia. Vasc Endovasc Surg. 2018;52(4):255-61. doi: 10.1177/1538574418761723.

Надійшла 03.08.2019 